\title{
Antibodies to cellular antigens in Greek patients with autoimmune rheumatic diseases: anti-Ro(SSA) antibody a possible marker of penicillamine-D intolerance
}

\author{
H. M. MOUTSOPOULOS, H. GIOTAKI, P. J. MADDISON, A. C. MAVRIDIS, \\ A. A. DROSOS, ANDF.N.SKOPOULI
}

From the Department of Medicine, School of Medicine, Ioannina Greece, and the Royal National Hospital for Rheumatic Diseases, Bath, England

SUMMARY One hundred and twenty-four sera from Greek patients with autoimmune rheumatic diseases (29 with systemic lupus erythematosus (SLE), 24 with scleroderma, 11 with primary Sjögren's syndrome (SS), and 60 with rheumatoid arthritis (RA) were tested for antibodies to nRNP, Sm, Scl-70, Ro(SSA), and La(SSB) cellular antigens. The incidence of these antibodies in the different groups of patients examined, did not differ overall from that described previously. It was noted, however, that antibodies to Sm were very infrequently found in Greek patients with SLE and anti-Ro positive patients with SLE did not have the clinical manifestations described by other workers. Finally, it was found that anti-Ro positive patients with RA experienced a high frequency of side effects from penicillamine-D. The significance of these findings is discussed.

In the last 20 years studies of serum autoantibodies against specific cellular antigens have improved our diagnostic and prognostic ability with respect to autoimmune rheumatic diseases. Thus antibodies to native DNA are highly specific for systemic lupus erythematosus (SLE) and indicate cases at risk for developing renal and nervous system manifestations, ${ }^{1}$ while antibodies to the Sm antigen have been found in patients with a benign form of the disease. ${ }^{2}$ High titres of antibodies to the nRNP characterise an overlap syndrome termed mixed connective tissue disease (MCTD) ${ }^{3}$ Antibodies to Scl-70 are specific for scleroderma, ${ }^{4}$ and antibodies to Jo-1 for polymyositis. ${ }^{5}$

In this communication we report the incidence of antibodies to certain cellular antigens in Greek patients with autoimmune rheumatic diseases and their correlation with clinical disease parameters.

\section{Materials and methods}

Sera were collected from 60 patients ( 15 males and 45 females, aged 23-78 years) with classical

Accepted for publication 22 March 1983.

Correspondence to Dr H. M. Moutsopoulos, School of Medicine, University of Ioannina, Ioannina, Greece. rheumatoid arthritis (RA) defined by criteria proposed by the American Rheumatism Association (ARA) ${ }^{6} ; 29$ patients ( 6 males and 23 females, aged 18-72 years) with SLE, according to ARA criteria ${ }^{7}$; 24 patients ( 2 males and 22 females, aged 27-64 years) with scleroderma ${ }^{8}$; and 11 patients (1 male and 10 females, aged 38-74 years) with primary Sjögren's syndrome (SS) ${ }^{9}$ Complete medical records were available for all these patients. They were consecutive, unselected admissions in the Department of Medicine, University of Ioannina, Greece. Twelve patients with scleroderma had diffuse systemic sclerosis and 12 had the CREST syndrome ${ }^{8}$ (calcinosis, Raynaud's phenomenon, oesophageal dysmotility, sclerodactyly, and telangiectasia) (Table 1). Thirty-two patients with RA had taken penicillamine-D $500 \mathrm{mg}$ daily for more than 6 months. Six of these patients developed side effects and treatment was discontinued. The remaining RA patients were on nonsteroidal anti-inflammatory agents alone or in combination with hydroxychloroquine.

All sera were tested without knowledge of clinical manifestations by immunodiffusion for antibodies to nRNP, Sm, Scl-70, Jo-1, Ro(SSA), and La(SSB) cellular antigens as previously described. ${ }^{8}$ 
Table 1 Incidence of antibodies to cellular antigens in Greek patients with autoimmune disease

\begin{tabular}{llllll}
\hline Patients & $n R N P$ & $S m$ & $S c l-70$ & $R o$ & $L a$ \\
\hline $\begin{array}{c}\text { SLE } \\
(\mathrm{n}: 29)\end{array}$ & $3(10 \cdot 3)^{*}$ & $1(3 \cdot 4)$ & 0 & $7(24 \cdot 1)$ & $2(6 \cdot 8)$ \\
$\begin{array}{c}\text { PSS } \\
(\mathrm{n}: 12)\end{array}$ & $1(8 \cdot 3)$ & $1(8 \cdot 3)$ & $4(33 \cdot 3)$ & $1(8 \cdot 3)$ & 0 \\
$\begin{array}{c}\text { CREST } \\
(\mathrm{n}: 12)\end{array}$ & $2(16 \cdot 6)$ & 0 & $1(8 \cdot 3)$ & $1(8 \cdot 3)$ & 0 \\
$\begin{array}{c}\text { SS } \\
(\mathrm{n}: 11)\end{array}$ & $1(9)$ & 0 & 0 & $4(36 \cdot 6)$ & $3(27 \cdot 2)$ \\
$\begin{array}{c}\text { RA } \\
(\mathrm{n}: 60)\end{array}$ & $1(1 \cdot 6)$ & 0 & 0 & $8(13 \cdot 3)$ & $1(1 \cdot 6)$ \\
\hline
\end{tabular}

* Percentage positive in parentheses.

\section{Results}

The frequency of these autoantibodies in our patients is shown in Table 1 . Eight patients $(6.4 \%)$ had antibodies to nRNP. The clinical manifestations of these patients are presented in Table 2. All had clinical features suggesting an overlap syndrome. Patient 1 had antibodies to $\mathrm{Sm}$ in addition to antibodies to nRNP. The patients with diffuse systemic sclerosis also had antibodies to Sm and Ro(SSA) and 2 patients (4 and 5) had antibodies to Ro(SSA) in addition to anti-nRNP. The 2 remaining patients with SLE and 2 patients with a CREST-like clinical picture had antibodies to $\mathrm{nRNP}$ alone. The incidence of antibodies to $\mathrm{Sm}$ in our SLE group was very low $(3.4 \%)$ (Table 1$)$, while that for anti-Ro(SSA) and anti-La(SSB) was as described by others. ${ }^{10}{ }^{11}$ AntiRo(SSA), however, was not associated with distinct clinical or laboratory factors (Table 3). Antibodies to Scl-70 were found exclusively in scleroderma

Table 2 Manifestations of the patients with antibodies to $n R N P$

\begin{tabular}{|c|c|c|}
\hline Patient & Diagnosis & Symptoms \\
\hline 1 & SLE & $\begin{array}{l}\text { Fever, arthritis, Raynaud's pheno- } \\
\text { menon, puffy hands, LE cells }\end{array}$ \\
\hline 2 & $\begin{array}{l}\text { Diffuse } \\
\text { systemic } \\
\text { sclerosis }\end{array}$ & $\begin{array}{l}\text { Fever, alopecia, scleroderma, } \\
\text { Raynaud's phenomenon, arthritis, } \\
\text { myositis, calcinosis, leucopenia. }\end{array}$ \\
\hline 3 & CREST & $\begin{array}{l}\text { Raynaud's phenomenon, puffy hands, } \\
\text { sclerodactyly, calcinosis }\end{array}$ \\
\hline 4 & SS & $\begin{array}{l}\text { Xerostomia, xerophthalmia, Raynaud's } \\
\text { phenomenon, discoid lupus }\end{array}$ \\
\hline 5 & RA & Arthritis, xerostomia, puffy hands \\
\hline 6 & SLE & $\begin{array}{l}\text { Raynaud's phenomenon, discoid rash, } \\
\text { alopecia, puffy hands, thrombo- } \\
\text { cytopenia }\end{array}$ \\
\hline 7 & SLE & $\begin{array}{l}\text { Fever, arthralgias, Raynaud's pheno- } \\
\text { menon, pleurisy, puffy hands, LE } \\
\text { cells }\end{array}$ \\
\hline 8 & CREST & $\begin{array}{l}\text { Sclerodactyly, Raynaud's phenomenon, } \\
\text { arthritis }\end{array}$ \\
\hline
\end{tabular}

Table 3 Manifestations of anti-Ro positive and negative SLE patients

\begin{tabular}{llc}
\hline Symptoms & $\begin{array}{l}\text { Anti-Ro } \\
\text { positive } \\
(n=8)\end{array}$ & $\begin{array}{c}\text { Anti-Ro } \\
\text { negative } \\
(n=21)\end{array}$ \\
\hline Alopecia & $3(37 \cdot 5)^{*}$ & $7(30)$ \\
Photosensitivity & $4(50)$ & $8(38)$ \\
Facial rash & $1(12 \cdot 5)$ & $7(30)$ \\
Discoid rash & 0 & $7(30)$ \\
Raynaud's phenomenon & $3(37 \cdot 5)$ & $7(30)$ \\
Mucosal ulcers & $2(25)$ & $6(28 \cdot 5)$ \\
Arthritis & $8(100)$ & $4(66 \cdot 6)$ \\
Myositis & $1(12 \cdot 5)$ & 0 \\
Serositis & $3(37 \cdot 5)$ & $10(46 \cdot 6)$ \\
Renal involvement & $1(12 \cdot 5)$ & $7(30)$ \\
CNS involvement & 0 & $3(14)$ \\
LE cells & $3(37 \cdot 5)$ & $14(66 \cdot 6)$ \\
Rheumatoid factor & $2(25)$ & 0 \\
Leucopenia (4000/mm $\left.{ }^{3}\right)$ & $3(37 \cdot 5)$ & $8(38)$ \\
Thrombocytopenia $\left(100000 / \mathrm{mm}^{3}\right)$ & 0 & $3(14)$ \\
\hline
\end{tabular}

${ }^{*}$ Percentages in parentheses.

SI conversion: leucocytes $4 \times 10^{9} /$; platelets $100 \times 10^{9} / 1$.

Table 4 RA patients treated with penicillamine- $D$

\begin{tabular}{|c|c|c|}
\hline & \multicolumn{2}{|l|}{ Patients } \\
\hline & $\begin{array}{l}\text { Anti-Ro } \\
\text { positive }\end{array}$ & $\begin{array}{l}\text { Anti-Ro } \\
\text { negative }\end{array}$ \\
\hline $\begin{array}{l}\text { Penicillamine-D treatment } \\
\text { Side effects }\end{array}$ & $\begin{array}{l}5 \\
5\end{array}$ & $\begin{array}{r}27 \\
1\end{array}$ \\
\hline
\end{tabular}

patients (Table 1). Of the SS patients one had antibodies to both nRNP and Ro(SSA) and 3 had anti$\mathrm{Ro}(\mathrm{SSA})$ in association with anti-La(SSB). One RA patient had antibodies to both nRNP and Ro(SSA) (patient 4, Table 2), one had antibodies to both $\operatorname{Ro}(\mathrm{SSA})$ and $\mathrm{La}(\mathrm{SSB})$, and $6 \mathrm{had}$ antibody to Ro(SSA) alone.

Five of the 8 anti-Ro(SSA)-positive RA patients received penicillamine-D for more than 6 months, and all developed side effects ( 1 rash, 1 fever, 1 proteinuria, 1 rash and leucopenia, and 1 decreased taste sensation). In 4 of these patients serum was available for testing prior to penicillamine treatment, and anti-Ro(SSA) was present in all cases. Of the 52 anti-Ro(SSA) negative RA patients 27 were treated with penicillamine-D but only one developed decreased taste sensation (Table 4).

\section{Discussion}

The antibody profile of the Greek autoimmune patients does not differ much from that described previously. ${ }^{11}$ Thus in Greek patients antibodies to nRNP were observed in patients with overlapping 
clinical features, ${ }^{3}$ autoantibodies to $\mathrm{Scl}-70$ were found predominantly in scleroderma patients, ${ }^{4}$ and antibodies to $\mathrm{Ro}(\mathrm{SSA})$ and $\mathrm{La}(\mathrm{SSB})$ were observed in association with all categories of connective tissue disease in an incidence similar to that reported by others. $^{12}$

Two differences were shown, however, in the Greek population tested. Firstly, antibody to Sm antigen was found infrequently in our SLE patients; secondly, anti-Ro(SSA) positive SLE patients did not express the clinical manifestations previously reported. ${ }^{12-14}$ The reason for these discrepancies may be that our patient sample is relatively small or that the genetic make-up of our population is different. Both hypotheses are under study.

Finally it was observed that anti-Ro(SSA) positive RA patients experienced a high frequency of penicillamine-D side effects. This finding is intriguing. Penicillamine is known to induce autoantibodies in RA patients. These autoantibodies are primarily organ specific antibodies and correlate with autoimmune side effects such as pemphigus and myasthenia gravis which generally develop after 3 months of treatment. ${ }^{15}$ A lupus-like syndrome may also be induced by penicillamine ${ }^{16}$ accompanied by serological abnormalities, including not only antinuclear antibodies but also antibody to DNA and hypocomplementaemia. ${ }^{17}$ Whether or not anti-Ro(SSA) antibody occurs in such patients is not yet known, but anti-Ro(SSA) was not detected in 50 patients with RA after treatment with penicillamine, $500 \mathrm{mg}$ a day, for at least 6 months. We doubt, however, whether penicillamine was the cause of anti-Ro(SSA) in these patients, since this antibody was detected in the serum prior to penicillamine therapy in 4 and in all patients Ro(SSA) persisted in the serum despite discontinuing the drug.

There may be genetic reasons why patients with anti-Ro(SSA) are more susceptible to develop penicillamine side effects. A strong association between the presence of anti-Ro(SSA) and HLA DR3 has been demonstrated, ${ }^{18}$ and the presence of this alloantigen has been associated with penicillamineinduced proteinuria. ${ }^{19}$ Anti-Ro was detected in 13\% of this Greek rheumatoid population, and on the basis of these observations we propose that this antibody may be a serological marker to predict penicillamine side effects in RA patients. Prospective serological and immunogenetic studies are in progress to answer these questions.

\section{References}

1 Miniter M F, Stollar B D, Agnello V. Reassessment of the clinical significance of native DNA antibodies in SLE. Arthritis Rheum 1979; 22: 959-68.

2 Winn G C. Identification of a clinical subset of SLE by antibodies to the Sm antigen. Arthritis Rheum 1979; 22: 1334-7.

3 Sharp G C, Irvin W S, May C M, et al. Association of antibodies to RNP and Sm antigens with mixed connective tissue disease, SLE and other rheumatic diseases. $N$ Engl J Med 1976; 295: 1149-55.

4 Tan E M, Rodnan G R, Carcia I, Moroi Y, Frotzler M J, Peebles C. Diversity of antinuclear antibodies in progressive systemic sclerosis. Arthritis Rheum 1980; 23: 617-25.

5 Nishikai M, Reichlin M. Heterogeneity of precipitating antibodies in polymyositis. Characteristics of the Jo-1 antibody system. Arthritis Rheum 1980; 23: 881-8.

6 Ropes M W, Bennett G A, Cobb S, Jacox R, Lessar R A. Revision of diagnostic criteria for rheumatoid arthritis. Bull Rheum Dis 1958; 9: 175.

7 Cohen A S, Reynolds W E, Franklin E C, et al. Preliminary criteria for the classification of systemic lupus erythematosus. Bull Rheum Dis 1971; 21: 643-8.

8 Rodnan G R. Progressive systemic sclerosis (scleroderma). In: McCarty D J, ed. Arthritis and allied conditions. 9th ed. Philadelphia: Lea and Febiger, 1979: 762-809.

9 Moutsopoulos H M, Webber B L, Vlagopoulos T P, Chused T M, Decker J L. Differences in the clinical manifestations of sicca syndrome in the presence and absence of rheumatoid arthritis. Am J Med 1979; 66: 733-6.

10 Reichlin M, Maddison R J. Soluble tissue autoantigens which precipitate with sera of patients with connective tissue diseases. In: Bentner E H, ed. Immunopathology of the skin. New York: Wiley, 1979: 357-62.

11 Moore T L, Weiss T D, Meucks S H, Baldassare A R, Zuckner J. Extractable nuclear antigens. Sem Arthritis Rheum 1981; 10: 309-18.

12 Alexander E L, Provost T T. Ro(Ss-A) and La(SS-B) antibodies. Sem Immunopathol 1981; 4: 253-73.

13 Wasicek C A, Reichlin M. Clinical and serological differences between systemic lupus erythematosus patients with antibodies to Ro versus patients with antibodies to Ro and La.J Clin Invest 1982; 69: 835-43.

14 Maddison P J, Provost T T, Reichlin M. Serological findings in patients with 'ANA-negative' SLE. Medicine (Baltimore) 1981; 60: $87-94$

15 Camus J P, Homberg J C. Crouzet J, et al. Autoantibody formation in D-penicillamine treated rheumatoid arthritis. $J$ Rheumatol 1981; 7 (suppl): 80-3.

16 Walshe J M. Penicillamine and the SLE syndrome.J Rheumatol $1981 ; 8$ (suppl 7): 155-60.

17 Chalmers A, Thompson D, Stein H E, Reid G, Patterson C A. Systemic lupus erythematosus during penicillamine therapy for rheumatoid arthritis. Ann Intern Med 1982; 97: 659-63.

18 Bell D A, Maddison P J. Serologic subsets in systemic lupus erythematosus: an examination of autoantibodies in relationship to clinical features of disease and HLA antigens. Arthritis Rheum 1980; 23: 1268-73.

19 Panayi G S, Wooley P, Batchelor J R. Genetic basis of rheumatoid disease: HLA antigens, disease manifestations and toxic reactions to drugs. $\mathrm{Br}$ Med J 1978; ii: 1326-8. 